Maciej Rak

Uniwersytet Jagielloński, Kraków

maciej.rak@uj.edu.pl

\title{
LISTY IZYDORA KOPERNICKIEGO DO SEWERYNA UDZIELI Z LAT 1887-1891
}

Słowa klucze: historia ludoznawstwa, górale ruscy, „Zbiór Wiadomości do Antropologii Krajowej”

Keywords: history of ethnography, Lemkos, „Zbiór Wiadomości do Antropologii Krajowej”

Korespondencja Izydora Kopernickiego z przedstawicielami różnych nauk znalazła omówienie w kilku opracowaniach. Julian Talko-Hryncewicz (1925) opublikował dziewięć listów, które otrzymał od Kopernickiego. Trzy listy (dwa z lat 1866 i 1869 do Władysława Laskowicza i jeden z roku 1878 do Franciszka Duchińskiego) zostały omówione przez Michała Godyckiego (1958), a jeden (adresowany do Józefa Majera z roku 1870) znalazł się w artykule Henryka Barycza (1956). Bogatszą korespondencję Kopernickiego z trzema badaczami - Janem Karłowiczem (36 listów), Adamem Honoriuszem Kirkorem (7 listów) i Benedyktem Dybowskim (9 listów) omówił Adam Wrzosek (Kopernicki 1960). Równie obszerną publikacją są listy Kopernickiego do Oskara Kolberga (27 listów) i Kolberga do Kopernickiego (8 listów) w opracowaniu Marii Turczynowiczowej (Kolberg 1965, 1966, 1969).

1 Izydor Kopernicki (1825-1891), antropolog, lekarz, etnograf, od 1886 r. profesor nadzwyczajny UJ, od 1875 r. sekretarz Komisji Antropologicznej AU, pierwszy redaktor (w latach 1877-1891) „Zbioru Wiadomości do Antropologii Krajowej”, inicjator badań nad językiem polskich Cyganów, przyjaciel i powiernik Oskara Kolberga, autor ponad 100 prac, z czego 20 dotyczyło problematyki etnograficznej i etnologicznej, a kilka - dialektologii. 
W Archiwum Muzeum Etnograficznego im. Seweryna Udzieli w Krakowie (dalej: $\mathrm{AME}^{2}$ pod sygnaturą I/1889/Rkp znajduje się 11 listów i 6 kart pocztowych z lat 1887-1891. Dokładniej korespondencja ta przedstawia się następująco: rok 1887 - 2 karty pocztowe, 1888 - 1 karta, 1889 - 7 listów, 1 karta, 1890 - 3 listy, 1 karta, 1891 - list i karta. Z pewnością nie jest to całość, gdyż z treści listów wynika, że Kopernicki korespondował z Udzielą również przed rokiem 1887. O opublikowanie tej korespondencji tuż po śmierci Kopernickiego zabiegał Jan Karłowicz:

Jeżeli pomiędzy listami Kopernickiego do Pana [chodzi o Udzielę - M.R.] znajdą się zawierające rzeczy ogólniejsze, naukowe, to chętnie byśmy je w „Wiśle” powtórzyli (list Z 10 V 1892 r.; Rak 2012: 161).

Wówczas, czyli 120 lat temu, nie doszło to jednak do skutku.

Publikowane obecnie listy obejmują pięć ostatnich lat życia Kopernickiego i dotyczą jego badań ludoznawczych i prac redakcyjnych w „Zbiorze Wiadomości do Antropologii Krajowej" (dalej: ZWAK), w którym kilka artykułów umieścił m.in. Udziela. Korespondencja ta traktuje o zbieraniu materiałów do monografii o Łemkowszczyźnie, zawiera też relacje z podróży naukowych Kopernickiego po terenach zamieszkałych przez górali ruskich. Na historię nauki, w tym ludoznawstwa, składają się dzieje myśli, instytucji naukowych oraz konkretnych badaczy. W niniejszym opracowaniu po części jest mowa o każdym z tych elementów. Omawiając artykuły opublikowane w ZWAK bądź redagowane dla tego pisma, Kopernicki dawał wskazówki informujące o myśli panującej ówcześnie w ludoznawstwie oraz o teorii i sposobach opisu faktów. Uwagi o funkcjonowaniu ZWAK i Komisji Antropologicznej Akademii Umiejętności są drugim zagadnieniem składającym się na historię ludoznawstwa. Wreszcie informacje dotyczące samego Kopernickiego, a także Oskara Kolberga to przyczynki do dokładniejszego poznania tych badaczy.

Publikując listy Kopernickiego do Udzieli, zmodernizowałem pisownię i interpunkcję, niepewne odczytania oznaczyłem przez [?], w nawiasach kwadratowych rozwinąłem skróty, ujednoliciłem zapis dat oraz dodałem przypisy. W przypisach znalazły się tytuły publikacji, do których odwoływał się Kopernicki, a także objaśnienia niektórych realiów (zwłaszcza geograficznych) i nazwisk.

\section{Literatura i źródła}

BARYCZ H., 1956, Nieznany epizod z życia Izydora Kopernickiego. Starania w 1870 r. o Katedrę Anatomii Porównawczej w Uniwersytecie Jagiellońskim, „Przegląd Antropologiczny” t. 22, s. 196-209. FrYś-Pietraszkowa E., 2007, Izydor Kopernicki (1825-1891), [w:] E. Fryś-Pietraszkowa i A. Spiss (red.), Etnografowie i ludoznawcy polscy, sylwetki, szkice biograficzne, t. II, Wrocław - Kraków, s. 160-162.

2 Serdecznie dziękuję dr. Antoniemu Bartoszowi, dyrektorowi Muzeum Etnograficznego im. Seweryna Udzieli w Krakowie, za udostępnienie zbiorów archiwalnych. 
Godycki M., 1958, Trzy listy Izydora Kopernickiego jako przyczynek do naświetlenia jego charakteru i działalności, „Przegląd Antropologiczny” t. 24, z. 2, s. 466-472.

Kolberg O., 1965, 1966, 1969, Dzieła wszystkie, t. 64: Korespondencja, cz. I (1837-1876), t. 65: Korespondencja, cz. II (1877-1882), t. 66: Korespondencja, cz. III (1883-189o), oprac. M. Turczynowiczowa, Warszawa - Kraków.

Kopernicki I., 1960, Listy do Jana Karłowicza, Adama Honoriusza Kirkora i Benedykta Dybowskiego, wydał i wstępem opatrzył A. Wrzosek, „Przegląd Antropologiczny” t. 26, s. 56-132.

Polski słownik biograficzny, t. 1-48, Warszawa - Kraków 1935-.

RAK M., 2012, Listy Jana Karłowicza do Seweryna Udzieli z lat 1888-19oo, „LingVaria” nr 1 (13), s. $151-165$.

Talko-Hryncewicz J., 1925, Listy Izydora Kopernickiego do J. Talko-Hryncewicza (1887-1891), spisane $z$ autografów i wstępem zaopatrzone przez Juliana Talko-Hryncewicza, cz. I, „Archiwum Historii i Filozofii Medycyny oraz Historii Nauk Przyrodniczych”, t. 2, z. 1, 1925, s. 120-130; cZ. II, t. 2, z. 2, 1925, s. 269-284, cZ. III, t. 3, z. 1, s. 145-155.

1887

1. $(K)^{3}$

W[ielmożny] Pan

Seweryn Udziela

Kierownik Szkoły Ludowej w Ropczycach ${ }^{4}$

Kraków, d[nia] 22 maja 1887

Szanowny i Kochany Panie!

Nie pierwszy to raz już przychodzi mi na myśl, co w tej chwili, że tłumaczenie snów $^{5}$ jest przedmiotem zupełnie zapomnianym i zaniedbywanym przez wszystkich badaczy mądrości ludowej. Nic łatwiejszego zaś, jak dowiedziałem się o takich augurach i sybillach, udawać się do nich z wymyślonymi snami na rozmaite temata. Pochlebiając ich mądrości, zdobyć łatwo moc materiałów i wiadomości całkiem nieznanych o wieszczbiarstwie ludowym i ułożyć z tego sennik najciekawszy. Polecam ten przedmiot szczególnej uwadze Kochanego Pana i pozdrawiam najserdeczniej.

Szczerze kochający przyjaciel

I. Kopernicki

3 (K) - karta pocztowa; (L) - list.

4 Udziela był nauczycielem i kierownikiem szkoły w Ropczycach w latach 1879-1888 (z przerwą w roku 1885, kiedy kierował szkołą w Lipniku pod Bielskiem-Białą).

5 W zbiorach AME znajduje się rękopis Udzieli pt. Bibliografia senników, początek XX w., 24 karty, sygn. I/206/Rkp. 
Wielmożny Pan

Seweryn Udziela

Kierownik Szkoły Ludowej w Ropczycach

Kraków, d[nia] 24 maja 1887

Szanowny i Kochany Panie!

Cieszę się bardzo, że depeszą moją o snach trafiłem w dawną własną myśl Pańską. Oprócz uwag kilku zapisanych przez P[ana] Ciszewskiego ${ }^{6}$, które podaliśmy w IX ${ }^{7}$ tomie „Zbioru Wiadomości [do Antropologii Krajowej]”, nic podobnego nie mieliśmy, bo nikt się tym nie zajmował, nikt na to uwagi nie zwracał. Zbierać je i spisywać warto, to pewne, ale okoliczność ta, na którą Pan słusznie zwracają uwagę, że to wiele tłumaczeń snów pochodzi z drukowanych senników, krążących między ludem, godną jest zastanowienia.

Zupełny brak doświadczenia własnego w tej rzeczy nie pozwala mi służyć Panu żądaną radą stanowczą. Zdaje mi się wszakże najwłaściwszym i najpożyteczniejszym spisywać bez wyjątku wszystko, co się posłyszy, a potem dopiero, porządkując i sprawdzając, odłączyć i podać na czele tłumaczenie snów nieznane z senników, czysto ludowe, a w dodatku dołączyć w krótkości tłumaczenia czerpane z drukowanych senników i podać bibliograficzny opis tych ostatnich. Książeczki te muszą być wielce ciekawe. Jeżeli mają Pan sposobność nabyć pomalutku zbiór tych senników, to koszt poniesiony na to z wdzięcznością zwrócę w każdej chwili.

Szczęść Boże! Pozdrawiam z szacunkiem najpię[kniejszym]

I. Kopernicki

6 Stanisław Ciszewski (1865-1930), etnograf, redaktor „Prac Etnologicznych”, autor kilku słowniczków gwarowych, profesor Uniwersytetu Lwowskiego; kierował w nim Katedrą Etnografii i Etnologii.

7 Chodzi tu jednak o X tom ZWAK.

8 Mowa o artykule Ciszewskiego, Lud rolniczo-górniczy z okolic Sławkowa w powiecie olkuskim, ZWAK X, 1886, cz. I, s. 187-336; XI, 1887, cz. II, s. 1-129. 
Wielmożny Pan

Seweryn Udziela

Inspektor Rady Szkolnej Okręgowej w Gorlicach ${ }^{9}$

Kraków, d[nia] 16 kwietnia 1888

Szanowny i Kochany Panie!

Znajomemu Pańskiemu podobno, P[anu] Marcelemu Ciskowi, nauczycielowi z Żołyni ${ }^{10}$, posłano niedawno $\mathrm{z}$ Akademii odbitki drukowane jego rozprawy ${ }^{11}$ i honorarium pod wskazanym dawniej adresem do Żołyni - tam go przesyłka nie zastała i została zwrócona. Proszę bardzo przysłać mi adres jego obecny, adresując do biura Akademii Um[iejętności] - musiał on być przeniesionym dokądeś, o czym może Pan wiedzą, dlatego upraszam o przysłanie jego adresu.

Pozdrawiam po przyjacielsku, szczerze życzliwy

I. Kopernicki

1889

4. (L)

Kraków, d[nia] 18 lutego 1889

Szanowny i Łaskawy Panie!

Doręczony mi przez brata Pańskiego ${ }^{12}$ list z rękopisem ${ }^{13}$ Jego zastał mnie pogrążonego w tak naglących zajęciach, że obawiając się, abym znowu nie zawinił przed Panem zbyt długim milczeniem, urywam sobie pierwszą chwilkę możliwą, aby odpisać Kochanemu Panu (proszę mi przysłać adres swego brata medyka - zapomniałem go

9 Udziela był inspektorem szkolnym w powiatach gorlickim i grybowskim w latach 1888-1893.

10 Wieś w województwie podkarpackim, powiat łańcucki.

11 Chodzi o artykuł Ciska, Materiały etnograficzne z miasteczka Żolyni w powiecie przemyskim, ZWAK XIII, 1889, s. 54-83.

12 Chodzi o Mariana Udzielę.

13 Mowa prawdopodobnie o rękopisie artykułu S. Udzieli, Lud polski w powiecie ropczyckim w Galicji, ZWAK XIV, 189o, cz. I, s. 1-136, XV, 1891, cz. II, s. 53-180, XVI, 1892, s. 1-57. W AME zgromadzono też rękopisy 3 innych prac Udzieli dotyczących historii Ropczyc: 1) Notatki do historii Ropczyc, koniec XIX w., 49 kart, sygn. I/459/Rkp., 2) Zabytki prehistoryczne z okolic Ropczyc, koniec XIX w., 8 kart, sygn. I/114/Rkp., 3) Zabytki przedhistoryczne w okolicy Ropczyc, 1887, 8 kart i 1 tablica, sygn. I/47/Rkp. 
o to zapytać, a mam potrzebę widzieć [się] z nim rychło - proszę po prostu przysłać na karcie korespondencyjnej, tylko prędko).

Prawdziwie godną Pańskiej gorliwości naukowej i wielce pożyteczną jest baczność zwrócona na ślady miejscowe zabytków przeszłości przedhistorycznej. Zapiski tym razem przysłane przez Pana, chociaż nie są istotnym materiałem do naszej archeologii przedhistorycznej, bo nie zawierają w sobie opisu jakiegoś wyraźnie przedhistorycznego materialnego zabytku i w takim znaczeniu nie kwalifikują się do druku, lecz są wskazówką nader cenną dla archeologów, gdyż zwracają uwagę na tę miejscowość dość obiecującą. Przez to samo już oddałeś Kochany Panie dobrą zasługę archeologii. Nie omieszkam też wiadomość tę zakomunikować na posiedzeniu Komisji [Antropologicznej AU], mającym się odbyć niezadługo i prawdopodobnie sam skorzystam z wiadomości udzielonych przez Pana, ażeby zaraz po Wielkiejnocy d[niach] na 14-16 kwietnia lub na kilka dni w maju zjechać do Ropczyc dla zwiedzania i w danym razie zbadania mogiłek „na Jurku”, a głównie dla systematycznego rozkopania mogiły w Czarnej ${ }^{14}$. Zawczasu więc upraszam łaskawego Pana o towarzyszenie mi w tych poszukiwaniach i o wstawienie się do ks. Proboszcza Rutawskiego o opiekę nad tą obiecującą mogiłą do mego przyjazdu.

Doskonały plan nakreślony przez Pana dla objaśnienia tego dopisku dowodzi, że będzie Pan mógł z pożytkiem dla nauki zająć się poszukiwaniami archeologicznymi na miejscu, jeśli raz tylko obaczysz na praktykę, jak się należy brać do nich umiejętnie i systematycznie, wiedząc, o co chodzi w tego rodzaju poszukiwaniach. Przedtem jednak odradzam Panu najusilniej zaczepianie czynne tych zabytków, bo zamiast pożytku dla nauki, o który Panu samemu idzie, stałbyś się tylko szkodnikiem archeologicznym, jakimi są wszyscy dyletanci nasi. Proszę więc z tym się nie spieszyć, a poprzestać tymczasem na wywiadywaniu się o miejscowościach zawierających prawdziwe i widoczne zabytki przedhistoryczne (mogiły, cmentarzyska, grodziska) i swoim wpływem i radą zbawienną ochraniać je od zniszczenia. Z mojej strony postaram się dostarczyć Panu dzieł ogólnych i prac cząstkowych, które oznajmią Pana z tym przedmiotem i należycie przysposobią do własnych badań pożytecznych.

Spisane przez Pana podania i legendy o Gródku i innych miejscowościach są materiałem etnograficznym, lecz wcale nie archeologicznym, gdyż takie same w odmiennej formie powtarzają się one wszędzie i u nas, i gdzie indziej.

Istotnym materialnym śladem dawnych siedzib przedhistorycznych są skorupy naczyń glinianych nie polerowanych i nie toczonych na kole, lecz lepionych w ręku, wyroby krzemienne i z kamienia, chociażby w ułamkach, szczątki wyrobów brązowych z drutu, blaszek itp. oraz z żelaza, pucharki gliniane, kamienne, szklane, emaliowane itp. (a także kości ludzkie spalone lub niepalone, lecz bardzo stare). Gdzie się tego rodzaju przedmioty wyorują, wykopują lub przypadkiem znajdują, na to miejsce należy szczególną zwrócić uwagę i położenie ich zanotować dokładnie. Wydmy piaszczyste nad brzegami rzek i potoków bywają najczęstszymi miejscami podobnych znalezisk.

14 Chodzi tu prawdopodobnie o Czarną Sędziszowską w powiecie ropczycko-sędziszowskim, gmina Sędziszów Małopolski. 
Na nie proszę zwrócić uwagę do mojego przybycia, abyśmy je razem pilnie splądrowali, a jeżeliby z początkiem wiosny wyorano lub wykopano gdzie jakie skorupy stare, szczątki narzędzi kamiennych itp., to proszę to wszystko starannie zachować do obejrzenia, gdy przyjadę, lub przed tym przesłać mi przy jakiej sposobności.

Wyliczane przez Pana przedmioty starożytne: rękojeść szabli, mszał i dokumenta, kwalifikują się raczej do Biblioteki Jagiellońskiej i do Gabinetu Uniwersyteckiego Starożytności ${ }^{15}$ niż do Akademii. W oddanie ich tam chętnie pośrednictwo moje ofiaruję. Kula wydrążona musi być zwykłym granatem nierozpękłym, więc żadną starożytnością prawdopodobnie nie jest.

Materiały etnograficzne swoje i cudze, jakie Pan masz w gotowości, a stanowiące jakąś całość, np. swój opis obrzędów i uroczystości, chociażby niewykończone jeszcze, równie jak zebrane przez $\mathrm{P}$ [ana] Pająka materiały do obrzędów i przesądów - proszę mi przesłać jak najprędzej, abym mógł przedstawić na najbliższym posiedzeniu Komisji (najdalej do drugiego tygodnia), niewykończone rękopisy zwrócę Panu na powrót dla dokompletowania i przygotowania do druku, a do druku oddam dopiero do XII ${ }^{16}$ tomu, tj. w końcu tego lub na początku przyszłego roku. Zbawienną rzecz robisz, Kochany Panie, zachęcając nauczycieli ludowych do zbierania materiałów etnograficznych uratuje się przez to i zbierze dużo skarbów prawdziwych. Tylko niech nie stawią na pierwszym miejscu pieśni, które są już oklepane i przeklepane do zbytku.

Kończyć pora, więc upraszam o przysłanie jak najpiękniejsze materiałów etnograficznych swoich i P[ana] Pająka, chociaż in crudo dla tymczasowego uporządkowania i zarejestrowania - i ściskam Kochanego Pana z prawdziwym szacunkiem i szczerą życzliwością.

I. Kopernicki

Żadnego upoważnienia do zbierania starożytności od Akademii uzyskać niepodobna, gdyż ona podobnych mandatów nikomu nie wydaje, a tym bardziej osobom nienależącym do jej składu. Ten sam ef[ekt] osiągniesz Pan łatwo, wykazując się piśmiennym podziękowaniem od Uniwersytetu, otrzymanym za złożone do jego zbiorów przedmioty, a o takowe nie omieszkam postarać się.

Proszę mi wyraźnie napisać, czego Panu brakuje i czego Pan potrzebujesz najpilniej dla wtajemniczenia się w przedmiot i zadania archeologii przedhistorycznej, a najchętniej dostarczę Panu wszystko, szczególnie jeżeli czytasz po niemiecku. Szkoda, że nie po francusku, bo mam doskonały podręcznik do tego.

Nie psuj, Kochany Panie, tyle papieru niepotrzebnie, pisując do mnie na takich olbrzymich arkuszach z tak szerokimi marginesami! Proszę brać wzór ze mnie ${ }^{17}$, a listy Pańskie będą mi jeszcze milszymi.

15 Mowa tu o Gabinecie Archeologicznym UJ założonym w 1867 r. przez Józefa Łepkowskiego (1826-1894). Gabinet ten mieścił się między innymi w budynku Biblioteki Jagiellońskiej (Collegium Maius).

16 Artykuł Udzieli, o którym mowa - Lud polski w powiecie ropczyckim..., ukazał się w trzech częściach.

17 Część korespondencji, którą umieściłem pod podpisem Kopernickiego, znajdowała się na marginesach listu, niektóre listy były tak dokładnie zapisane, że nie było na nich wolnego miejsca. 


\section{Szanowny i Drogi Panie!}

Jakże dawno już pragnę i potrzebuję wznowić miłą i pożądaną dla siebie korespondencję z Kochanym Panem, a tu coraz nowe i coraz to bardziej naglące zajęcia ustawicznie mię od tego odciągały.

Łaskawie mi ofiarowane wielce ciekawe oba studia Pańskie o Ropczycach ${ }^{18}$, a jeszcze bardziej list Pański, tak uprzedzająco uprzejmy, który wczoraj otrzymałem, tak mię ujęły, że oto korzystając z niedzieli, wszelkie inne korespondencje usuwam na stronę, ażeby do woli pogawędzić sobie z Kochanym Panem.

Przede wszystkim dzięki najserdeczniejsze za nieocenione przyrzeczenie dostarczenia mi materiałów etnograficznych z Łemkowszczyzny ${ }^{19}$. O to właśnie miałem upraszać Pana, posyłając Mu moje sprawozdanie z podróży, gdy sam Pan najpierwszy ofiarujesz mi twą pomoc tak pożądaną. Cenną mi jest ona i niezbędną tym bardziej, że na nikogo innego liczyć nie mogę. W podróży mojej znajdywałem ze strony duchowieństwa ruskiego przyjęcie najgościnniejsze i pomoc chętną we wszystkim, a nawet od wielu osób przyrzeczenia solenne, że każdy po trosze uzbiera dla mnie i przyszle to i owo ze swojej miejscowości. Po powrocie do Krakowa rozesłałem takim osobom kilkanaście egz[emplarzy] mego Przyczynku do etnografii ludu ruskiego na Wołyniü ${ }^{20}$, ażeby mieli próbkę tego, o co mi chodzi i co każdy bez trudności wkoło siebie zebrać może. Następnie każdemu, pod czyim dachem byłem i z kim się zetknąłem w pod róży, posłałem moją relację o góralach ruskich $^{21}$. Na to zaledwo 6-ciu odpowiedziało mi grzecznym podziękowaniem nic nieobiecującym, a trzech tylko rzeczywiście przysłało mi to, co mogli, za co im jestem wielce obowiązany. W tej liczbie jednym z pierwszych był przezacny ks. dziekan Kapyściański ze Śnietnicy ${ }^{22}$ i poczciwy młodzieniec P[an] Laszenik ze Szczawnika ${ }^{23}$ pod Muszyną. Znaczna zaś większość ani się odezwała. Na duchowieństwie więc, bodaj czy nie zawiodłem

18 Dokładnie nie wiadomo, o które prace tu chodzi, o Ropczycach Udziela napisał bowiem cztery rozprawy (por. przypis 13), ale tylko jedna ukazała się drukiem.

19 Udziela we wstępie do książki Ziemia łemkowska przed półwieczem (Lwów 1934) pisał (s. 7), że od czasu nawiązania korespondencyjnej współpracy z Kopernickim przesyłał mu notatki dotyczące Łemków. Nie wiadomo jednak, o które rzeczy dokładnie chodziło. W AME znajduje się liczący 52 karty rękopis Udzieli, Rusini - Łemki w pow. Gorlice i Grybów, zwyczaje i poglądy tyczace się stosunków pomiędzy rodzicami a dziećmi, który jednak nie mógł być przywoływany w tym liście, gdyż jest oznaczony datą 1891, sygn. I/61/Rkp.

20 Mowa o artykule Przyczynek do etnografii ludu ruskiego na Wołyniu. Z materiałów zebranych przez p. Zofię Rokossowska we wsi Jurkowszczyźnie w powiecie zwiahelskim, ZWAK XI, s. 130-228.

21 Chodzi o artykuł O góralach ruskich w Galicji. Zarys etnograficzny według spostrzeżeń w podróży, odbytej w końcu lata 1888 r., ZWAK XIII, s. 1-34.

22 Śnietnica (łemk. Снітниия) - wieś na Łemkowszczyźnie w powiecie gorlickim, gmina Uście Gorlickie.

23 Szczawnik (łemk. Щавник) - wieś na Łemkowszczyźnie w powiecie nowosądeckim, gmina Muszyna. 
się najzupełniej, a przynajmniej na ich pomoc liczyć nie mogę. Z nauczycielami ludowymi na Łemkowszczyźnie nie spotkałem się nigdzie. Dalej między Bojkami i Hucułami poznałem kilku, których usilnie zachęcałem do spisywania tych rzeczy, obiecując nawet wynagrodzenie odpowiednie i posłałem im na wzór Etnogr[afię] Wołynia ${ }^{24}$, lecz dotąd ani świstka od żadnego nie mam. Wobec tego w innej okolicy, tj. na Bojkowszczyźnie, Tucholszczyźnie ${ }^{25} \mathrm{i}$ dalej postarałem się już i poniekąd odkryłem sobie nowe drogi i źródła. Na Łemkowszczyźnie miałem i mam tylko jednego Pana, więc, dziękując Mu najszczerzej za Jego uprzedzającą gotowość, upraszam najusilniej o tak potrzebną mi pomoc. Czego mi potrzeba, tego Panu wyszczególniać nie potrzebuję, bo tam od lat tylu zajmując się tym wzorowo, wiedzą, czego szukam. Wymieniłem to zresztą przy końcu mojej broszury o góralach ${ }^{26}$. Pozostaje mi tylko prosić Drogiego Pana, abyś na moją intencję wezwał i zachęcił do tego swoich nauczycieli ludowych (które p[unk]ty należą do okręgu szkolnego Pańskiego? Jak dalece liczyć można na współudział Pańskich nauczycieli w zbieraniu materiałów - proszę mi o tym napisać kiedyś). Ustne wskazówki Pańskie wystarczą, a z mojej strony oświadczam szczerą gotowość wynagrodzenia każdego według uznania samego Pana i na każde zawołanie Pańskie odpowiednią kwotą służyć Mu będę. Dla ułatwienia im spisywania niech również piszą po rusku, jeżeli im to łatwiej jest niż po polsku. Ma się rozumieć bajki, pieśni, zagadki itp. muszą być napisane tylko po rusku i pisownia ruska etymologiczna lub fonetyczna, to mi wszystko jedno - jeżeli polskiej użyć nie chcą lub nie umieją. Za wszelkie szczegóły o mieszkaniach, bycie i ubiorach z rozmaitych okolic, jeżeli można, objaśnione rysunkami, chociażby nieartystycznymi, będę również obowiązany. Mam wprawdzie o tym dużo notatek własnych, których w sprawozdaniu mym teraz nie podawałem, lecz dla uzupełnienia ich wszelkie nowe bardzo mi się przydadzą. Przede wszystkim, jeżeli Pan sam ma pod tym względem jakie spostrzeżenia prostujące i uzupełniające mój opis, to bardzo o nie upraszam.

Nowe materiały etnograficzne z Ropczyc, ma się rozumieć, przyjęte będą w Komisji [Antropologicznej] z należytym uznaniem, a przeze mnie z zajęciem wyłącznym. Proszę je przysłać jak można najprędzej, chociażby niewykończone, ażebym mógł przedstawić na najbliższym posiedzeniu i drukować już w tym roku nawet, jeżeli się to okaże możliwym. Po przedstawieniu w Kom[isji] mogę Panu rękopisy zwrócić dla ostatecznego uporządkowania i wykończenia, a potem sam z największą przyjemnością zajmę się drukiem i korektą, ażeby tym wywdzięczyć się Drogiemu Panu za usługę, którą mi tak łaskawie obiecujesz.

Pozdrawiam Kochanego Pana najserdeczniej, zawsze z wysokim szacunkiem i przyjacielską życzliwością, szczerze mu oddany

I. Kopernicki

24 Chodzi tu o Przyczynek do etnografii ludu ruskiego...

25 Tucholszczyzna Karpacka to region w Beskidach Wschodnich nad rzekami Oporem i Orawą, zamieszkały przez Tucholców, graniczący z Bojkowszczyzną i Huculszczyzną.

26 Mowa tu o artykule $O$ góralach ruskich w Galicji... 


\section{6. (L)}

Kraków, d[nia] 2 kwietnia 1889

Szanowny i Kochany Panie!

Przepraszając bardzo za przetrzymywanie poruczonego mi rękopisu, takowy zwracam. Wcześniej nie mogłem dla rozmaitych zajęć naglących, które mi nie dawały czasu wolnego do napisania tych kilku słówek niezbędnych.

Zbiór Pański doskonale poczęty, tak jak dawniejszy drukowany ${ }^{27}$, gdy się uzupełni i pomnoży za staraniem Pańskim, będzie przyczynkiem naukowym równie cennym i znakomitym. Życzę więc szczęścia w dalszym podawaniu. Rozpiski, zaznaczone dotąd, skąpe uzupełnisz i brakujące jeszcze dodasz, gdy zechcesz rozszerzyć obszar swych badań, nie poprzestając na ciasnej wyłącznie okolicy Ropczyc i wsi sąsiednich. Radzę więc rozciągnąć się dalej na powiaty sąsiednie, o ile pod względem etnograficznym należą do wspólnego obszaru i przy pomocy kolegów zachęconych do tejże roboty uzbierać, co potrzeba.

Co się tyczy ostatecznego przygotowania zebranych materiałów, pozwalam sobie podać następujące rady:

1. Nie rozszerzać się nad szczegółami powszechnie znanymi i opisanymi przez innych (np. na Wilję B[ożego] Narodzenia), lecz w krótkich wyrazach zaznaczyć istnienie tych szczegółów, oszczędzając miejsca dla rzeczy nowych i gdzie indziej nieznanych.

2. Przy ostatecznym uporządkowaniu szczegółów w każdym rozdziale ułożyć je tak, aby jednorodne były obok siebie, a różnorodne grupy po kolei wypływały niejako jedna z drugiej przy opowiadaniu i wiązały się w jeden obrazek. Czytelnikowi ułatwi to studiowanie lepiej niż suche skatalogowanie faktów.

3. W tym celu, ażebyś Pan uniknął mozolnej pracy przepisywania swoich notatek do druku, radzę pisać na jednej stronie karty, a drugą pozostawić czystą. Dla oszczędzenia papieru możesz sam zapisywać na kartkach dwa razy mniejszych bez żadnych marginesów, tylko szczegół jeden od drugiego niech będzie przedzielony linijką, dlatego aby później przy porządkowaniu materiałów każdy szczegół osobno odcięty nożycami dał się postawić na właściwym miejscu. Wszelkie uwagi, cytaty, przypiski itp. mogą być później dopiero dopisane na odwrotnej stronie.

Rozpisałem się o tym dlatego, żem został pozbawiony miłej nadziei odwiedzenia Pana i archeologowania z Nim razem po świętach. Wylosowany do sądu przysięgłych ${ }^{28}$, tej wiosny ruszyć się z miejsca nie mogę i zamierzoną wycieczkę odłożyć muszę na koniec września lub początek października. Do tego więc czasu zamawiam sobie łaskawą pomoc

27 Chodzi o artykuł Materiały etnograficzne zebrane z miasta Ropczyc...

$28 \mathrm{Na}$ władzę sądowniczą w Galicji składała się między innymi ława przysięgłych, do której losowo byli wybierani obywatele. $\mathrm{W}$ ten sposób realizowano zasadę udziału czynnika społecznego w wymiarze sprawiedliwości. 
Kochanego Pana i upraszam o opiekę nad miejscami, które mamy zbadać, szczególnie nad owym żalnikiem ${ }^{29}$ prawdopodobnym w Czarnej. Natomiast znanej mi gorliwości Pańskiej polecam gorąco sprawę inną, tj. zbieranie przedmiotów na wystawę etnograficzną według programu, którego 5 egz[emplarzy] dołączam dla Pańskiego użytku. Prawdopodobnie otrzymasz Pan wezwanie do tegoż z innej strony, tj. od miejscowej Rady Powiatowej, którą Komisja Wystawowa prosiła o zajęcie się tym i powołanie do tego nauczycieli ludowych. Niezależnie jednak od tego, gdybyś nie był wezwanym, możesz Pan wielce przysłużyć się wystawie, zbierając potrzebne przedmioty za osobistym staraniem przy pomocy swoich kolegów i znajomych gospodarzy. Gdybyś potrzebował większej ilości egzemplarzy, to proszę zażądać kartką pocztową, a wnet przyszlę.

Kończę, życząc Świąt wesołych i pomyślności wszelkiej, szczerze szanujący i kochający sługa

I. Kopernicki

\section{7. (L)}

Kraków, 15 kwietnia 1889

Szanowny i Drogi Panie!

Bodaj czym się nie spóźnił z tym listem, ale tak byłem ciągle zakłopotany w ostatnim tygodniu, że z dnia na dzień odkładając, na pisanie zabrać się nie zdołałem.

Czy nie mógłby Pan przez swoich podkomendnych nauczycieli wiejskich lub przez znajomych księży zebrać dla mnie z paru miejsc głównych pisanki wielkanocne Łemków, dobrane i przygotowane według naszej instrukcji drukowanej, którą Panu w 3 egz[emplarzach] do użytku, tj. do posłania komu należy załączam. Przesłać mi proszę zebrane razem jako posyłkę niefrankowaną, paczkę lub jako fracht koleją. A gdyby za nabycie i przygotowanie pisanek zapłacić przyszło, to chętnie ofiaruję się zapłacić do wysokości 5 c[entów] za sztukę. Mam nadzieję, że znajdziesz Pan łatwiej dla mnie ludzi, którzy tym zająć się zechcą, chociażby dla dogodzenia Panu. Ja prosiłem o toż ks. dziekana Kapyściańskiego ze Śnietnicy, lecz nie jestem pewny skutków. A chce mi się bardzo mieć okazy pisanek łemkowskich dla uzupełnienia mojego zbioru i za dostarczenie ich wielce obowiązany będę.

Życzenia najszczersze zasyłam na zbliżające się Święta i zastaję zawsze z szacunkiem prawdziwym, najżyczliwiej oddany Wam

I. Kopernicki

29 Cmentarz. 


\section{8. (L)}

Kraków, d[nia] 31 lipca 1889

Szanowny i Kochany Panie!

Około 10-15 sierpnia mam się puścić powtórnie na kilkutygodniową wędrówkę w Karpaty, do górali ruskich. Po drodze pragnę koniecznie tym razem wstąpić do Gorlic, dla widzenia się z Kochanym Panem i porozmawiania z Nim o wielu rzeczach potrzebnych mi dla zamierzonej etnografii górali ruskich ${ }^{30}$.

Proszę mię przeto kilku słowy na karcie zawiadomić łaskawie, czy i kiedy zastać mogę Pana w domu i jakie pół dnia przepędzić z Nim bez żadnej mitręgi i kłopotu dla Pana. Gdyby odwiedziny moje w tej porze były Panu nie na rękę, to proszę mię szczerze o tym uprzedzić. W takim razie zmienię plan swej podróży i tak się urządzę, ażeby dopiero w powrocie na początku października wstąpić do Pana. Jeżeli zaś teraz zajechać mogę, to proszę mi z łaski swojej zawczasu obmyślić pierwszą dogodną stację obserwacyjną w swoim okręgu w okolicy Gładyszowa ${ }^{31}$ lub jednak lepiej Małastowa ${ }^{32}$, gdzie mógłbym z korzyścią zatrzymać się na 2 lub 3 dni dla zebrania potrzebnych wiadomości i materiałów o Łemkach przy pomocy miejscowego nauczyciela ludowego lub księdza itp. Z Gorlic albowiem zamierzam od Małastowa lub Gładyszowa objechać pas północny Łemkowszczyzny w tej okolicy równoległy do przeszłorocznej mej drogi wzdłuż granicy węgierskiej i przez Żmigród ${ }^{33}$ dążyć ku Krasnu ${ }^{34}$ dla porównawczego poznania graniczących z sobą osad ruskich i polskich.

Niech Pan też będzie łaskaw zebrać pewne wiadomości o prażnikach ${ }^{35}$ cerkiewnych, jarmarkach i targach dwutygodniowych w tej okolicy, którą zamierzam przebywać, ażebym mógł skorzystać $\mathrm{z}$ takich okazji dla poznania miejscowej ludności w większej masie naraz. W oczekiwaniu rychłej odpowiedzi pozdrawiam Kochanego Pana najserdeczniej, powtarzając Mu wyrazy mego prawdziwego szacunku.

Sługa życzliwy

I. Kopernicki

30 Śmierć Kopernickiego 24 IX 1891 r. pokrzyżowała te plany. Nieuporządkowane materiały o góralach ruskich (ze stu fotogramami i licznymi odręcznymi szkicami) przeglądał między innymi Karłowicz (por. list do S. Udzieli z $10 \mathrm{~V} 1892$ [w:] Rak 2012: 161).

31 Gładyszów (łemk. Гладищiв) - wieś na Łemkowszczyźnie w powiecie gorlickim, gmina Uście Gorlickie.

32 Małastów (łemk. Маластів) - wieś na Łemkowszczyźnie w powiecie gorlickim, gmina Sękowa.

33 Stary Żmigród bądź Nowy Żmigród - wsie w powiecie jasielskim, gmina Nowy Żmigród.

34 Krasna (ukr. Красна) - wieś zamieszkała przez Zamieszańców, powiat krośnieński, gmina Korczyna.

35 Łemk. odpust. 


\section{9. (K)}

Wielmożny Pan

Edward Udziela, mecenas w Żywcu

dla oddania bratu swemu P[anu] Sewerynowi

Kraków, d[nia] 20 sierp[nia] 1889

Szanowny i Drogi Panie!

Wiadomość przed kilku dniami otrzymana przynosi o odkryciu bardzo ciekawego i wiele obiecującego cmentarzyska w okolicach Rohatyna ${ }^{36}$, które należy zbadać niezwłocznie, sprawiła przewrót zupełny w dawnym planie mej tegorocznej wędrówki. We czwartek d[nia] $15 \mathrm{t}$ [ego] m[miesiąca] udaję się wprost do Rohatyna, gdzie zabawię, ile potrzeba $\mathrm{w}$ te dnie, tj. 8-12 dni, a stamtąd dopiero puszczam się w góry, zaczynając od Mikuliczyna ${ }^{37}$ nad Prutem, posuwać się będę ku zachodowi i podróż moją na Gorlicach zakończę, dokąd od Krasna wiejskimi drogami przez Małastów przybędę przed 15 października. Lubo zastanę Szanownego Pana już zajętym swą służbą, lecz podziękować Mu muszę za wszystko, co dla mnie zebrałeś i za to, czym mię w przyszłości obdarzyć przyrzekasz. Do widzenia więc za 2 miesiące, polecam się życzliwej pamięci i pozdrawiam po przyjacielsku

I. Kopernicki

10. (L)

Kraków, d[nia] 24 listop[ada] 1889

\section{Szanowny i Drogi Panie!}

Przed paru dniami miałem prawdziwą przyjemność otrzymać Pański Lud rop$c z y c k i^{38}$. Przejrzawszy go z wielkim zajęciem, tę piękną, prawdziwie wzorcową pracę, przekonałem się z najwyższym zadowoleniem, że zawiera w sobie tyle świeżych i niezmiernie ciekawych wiadomości szczególnie o naszym ludzie mieszczańskim, a wszystko w niej jest tak gruntownie przedstawione i porządnie ułożone, że z wyjątkiem pieśni nic z niej ująć ani zmienić, ani podobna dodać nie można [sic]. Pieśni jedne, jak sam Pan to znajdujesz, potrzebują uporządkowania, a - jak mnie się zdaje po powierzchownym przejrzeniu dla samego także porównania $\mathrm{z}$ wydrukowanymi już zbiorami Kolberga i innych, dlatego aby z nich opuścić pieśni i melodie już znane i zaopatrzyć w przypiski ze wskazówkami na znane już warianty. Bez żadnego też uszczerbku dla całości można będzie opuścić garstkę niewielką przysłów, od których

36 Rohatyn (ukr. Рогатин) - miasto na zachodzie Ukrainy, obwód iwanofrankowski.

37 Mikuliczyn (ukr. Микуличин) - wieś na zachodzie Ukrainy, obwód iwanofrankowski.

38 Lud polski w powiecie ropczyckim... 
od dawna istnieje uchwała Komisji, ażeby je odkładać do ogólnego zbioru ${ }^{39}$, który ma być wydany w całości systematycznie opracowanej. Jeżeliby Panu zaś koniecznie zależało na podaniu ich $\mathrm{w}$ tej pracy, to radziłbym wybrać $\mathrm{z}$ nich same tylko czysto miejscowe, i to najbardziej charakterystyczne, i utworzyć z nich rodzaj mozaiki psychologiczno-obyczajowej, którą by się wstawiło do rozdziału o charakterystyce ludu. Miło mi będzie bardzo przedstawić tę pracę na najbliższym posiedzeniu Komisji, gdzie będzie z należnym uznaniem przyjęta. Wydrukować jej całość w jednym tomie niepodobna, bo zajęłaby większą połowę działu na to przeznaczonego, a to jest niemożebnym, gdy mamy dużo prac innych, które w tym tomie drukować musimy. Ażeby wszakże w odbitkach dla Pana przeznaczonych praca ta mogła wyjść w całości, to się poradzi w taki sam sposób, jak się już stało z kilku obszerniejszymi pracami wydanymi w „Zbiorze Wiadomości [do Antropologii Krajowej]”, np. Ciszewskiego ${ }^{40}$, Cinciały ${ }^{41}$ i Karłowicza ${ }^{42}$, tj., że się jedną połowę aż do Bajek wydrukuje na końcu tomu XIV, a druga połowa (Bajki i pieśni) rozpoczną tom następny, który drukować się będzie w ślad za poprzednim. Odbitki będą miały osobną paginację i połączone obie części $\mathrm{w}$ jeden tom $\mathrm{z}$ osobną kartką tytułową utworzą dzieło całe i osobne. Na tym Pan nic nie stracisz, owszem zyskasz przeszło pół roku czasu na uporządkowanie pieśni i zaopatrzenie ich w przypiski, o których wspominałem. Mapka p[owia]tu ropczyckiego oraz heligrawiury obu grup typowych ludu w jego ubiorach będą dołączone do 1. części, a o kilka wizerunków domów postaram się w redakcji „Wisły”. Jeżeli do opracowania pieśni potrzebna Panu będzie seria $L u d u$ Kolberga, których podobno nie posiadasz, to $\mathrm{z}$ największą gotowością służyć mogę Panu moim własnym egzemplarzem na cały czas na to Mu potrzebny.

Za dołączone do przesyłki materiały łemkowskie do mego własnego użytku dziękuję Panu najserdeczniej. Pieśni z Małastowa i Ropicy ${ }^{43}$, a także z Boguszy ${ }^{44}$ są najlepsze i tych sporo wybiorę do użytku. Z Krywego ${ }^{45}$ większa [sic] podania (12 wszystkich) zakrawają na apokryfy książkowe, kunkowskie ${ }^{46}$ po największej części bardzo wadliwie spisane. Zagadki, choć nieliczne, lecz wszystkie są dobre. Opis obrzędów weselnych, z jakiej mianowicie wsi p[owia]tu grybowskiego pochodzi, tego nie wiem i chciałbym

39 Być może chodzi tu o inicjatywę Samuela Adalberga Księga przysłów, przypowieści i wyrażeń przysłowiowych polskich. Udziela za pośrednictwem Karłowicza przekazywał Adalbergowi zebrane przez siebie przysłowia. 40 S. Ciszewski, Lud rolniczo-górniczy z okolic Sławkowa w powiecie olkuskim...

41 A. Cinciała, Pieśni ludu śląskiego z okolic Cieszyna, ZWAK IX, 1885, s. 173-299.

42 J. Karłowicz, Podania i bajki ludowe zebrane na Litwie, ZWAK XI, 1887, cz. I, s. 229-293, ZWAK XII, 1888, s. 1-59.

43 Ropica Górna (dawniej Ropica Ruska, łemk. Ропиця Руська) - wieś na Łemkowszczyźnie w powiecie gorlickim, gmina Sękowa.

44 Bogusza (łemk. Богуща) - wieś na Łemkowszczyźnie w powiecie nowosądeckim, gmina Kamionka Wielka.

45 Krywe (Krzywe, bojk. Криве) - wieś na Bojkowszczyźnie w powiecie leskim, gmina Cisna.

46 Kunkowa (łemk. Кунькова) - wieś na Łemkowszczyźnie w powiecie gorlickim, gmina Uście Gorlickie. 
się dowiedzieć. P[an] Piotr Frymkiewicz ułożył ten opis zbyt powierzchownie i rzecz cała przedstawia się całkiem inaczej niż w znanych mi opisach z innych miejscowości. Pomimo to jako materiał dodatkowy przyda mi się dla niektórych szczegółów. Dziękuję więc i za to jak najuprzejmiej równie jak za łaskawe przyrzeczenie zdobycia mi nowych materiałów. W tych pieśni nie są mi zbyt pożądanymi, bo tych mam już pod dostatkiem. Za to proszę chociaż o najbardziej in crudo opisane zwyczaje i obrzędy domowe i doroczne, o wierzenia, gusła, czary, demonologię, także o bajki i zagadki dobrze spisane. Lubo w tej mierze liczę poniekąd na łaskawą pomoc Kochanego Pana, jednakże, jak mi się zdaje, nie obejdzie się bez tego, abym na połów tych rzeczy sam się nie wybrał na Łemkowszczyznę na czas jakiś. Już mi się nawet raić zaczyna w myśli wycieczka na święta wielkanocne ruskie, które w tym roku w tydzień po naszych przypadają. W takim razie będzie mi chodziło o upatrzenie paru miejscowości takich, gdzie mógłbym liczyć z pewnością na pomoc miejscowego proboszcza, a także nauczyciela, diaka i wójta, że mi świadomych ludzi do tych badań zwerbują. Jedno takie miejsce mam na widoku w Grabie $^{47}$ w pow[iecie] liskim ${ }^{48}$, a drugie w Swoim okręgu, zechciej mi zawczasu pomyślić, Drogi Panie.

Żałuję niezmiernie, że i tym razem nie udało mi się zboczyć do Gorlic w powrocie z mojej wędrówki. Ale tak się stało nieszczęśliwie, że mię śniegi 18 września zaskoczyły w górach nad Łomnicą ${ }^{49}$, tak że dalszej podróży zaniechać musiałem, a przy tym wiadomości otrzymane $\mathrm{z}$ domu tak mię nagliły do powrotu, że z Bulechowa ${ }^{50} \mathrm{aż}$ do domu bez odpoczynku pośpieszyć musiałem.

Niedługo po powrocie do Krakowa wyczytałem z niezmierną radością wiadomość w gazetach o zawiązanym przez Pana kółku etnograficznym ${ }^{51}$. Winszując Panu z całego serca tak zacnego i pożytecznego przedsięwzięcia, chciałem to wyrazić Mu natychmiast, lecz gdy mi wówczas naglące zatrudnienia moje nawet na to nie zostawiały chwilki wolnej, korzystam z pierwszej tej sposobności, aby wypowiedzieć Kochanemu Panu całe moje uwielbienie dla tak zacnej i dzielnej Jego inicjatywy. Z radością też prawdziwą dowiaduję się, że pod kierunkiem Pańskim zamysł ten podanym mi został, gdy na rok przyszły spodziewasz się dojrzałych owoców z prac Kółka - Szczęśćże Wam Boże, a ponieważ z całego serca pragnę być Wam w tym użytecznym, więc oto sam radzę Panu, abyś natychmiast wystosował pismo do Komisji Antropologicznej z zawiadomieniem o zawiązaniu się Kółka, o jego zadaniach i zebranych już przez niego materiałach dla użytku nauki i w nim upraszał Komisję o ofiarowanie Wam kompletu całego „Zbioru Wiadomości [do Antropologii Krajowej]”. Jednocześnie

47 Grab (łemk. Граб) - wieś na Łemkowszczyźnie w powiecie jasielskim, gmina Krempna.

48 Powiat leski (do 1931 r. używano nazwy powiat liski) z siedzibą w Lesku.

49 Łomnica (ukr. Лімниця) - rzeka na Ukrainie, prawy dopływ Dniestru, wypływa z góry Basztuł w Gorganach.

50 Bolechów (ukr. Болехів) - miasto na zachodzie Ukrainy, w okręgu iwanofrankowskim.

51 Kółko etnograficzne, o którym mowa, zostało założone przez Udzielę w Gorlicach 22 V 1889 r. Skupiało nauczycieli, którzy zamierzali przygotować monografię etnograficzną powiatu gorlickiego. 
na karcie korespondencyjnej zawiadomisz mię Pan o wysłaniu tego pisma, a ja na posiedzeniu Komisji poprę wasze żądania jak najenergiczniej.

Nie zawadzi też z podobną prośbą, bardzo gorącą i grzeczną udać się do O[skara] Kolberga, prosząc go o Lud i Mazowsze - adres jego ul. Sławkowska $29^{52}$. Kolberg niezawodnie powie mi o waszej odezwie, więc ja Waszą prośbę poprę tak, że może bezpłatnie lub przynajmniej za pół ceny dostaniecie.

Z prawdziwym szacunkiem ściskam Drogiego Pana po przyjacielsku

$$
\text { I. Kopernicki }
$$

\section{1. (L)}

Kraków, d[nia] 12 grudnia 1889

\section{Szanowny i Drogi Panie!}

Cieszę się niezmiernie, iż wszystko się stało według życzeń Pańskich i najszczerszych myśli moich i chęci dla Niego - wczoraj odbyło się posiedzenie Komisji Antropologicznej, na którym z prawdziwą przyjemnością przedstawiłem Lud polski z okolic Ropczyc oraz odezwę Pańską w sprawie Kółka etnograficznego. Pierwszy, rozdzielony na 2 części, drukować się będzie w XIV i XV tomach „Zbioru Wiadomości [do Antropologii Krajowej]”, przy czym druk 1. części rozpocznie się niebawem; 2. zaś część, tj. pieśni itd., odeszlę Panu wkrótce, skoro swobodniejszym będę nieco, dla ostatecznego uporządkowania i przygotowania na przyszłą późną jesień. Honorarium za 1. część przeszle się Panu po jej wydrukowaniu, a resztę po wydrukowaniu 2. części razem z 50 odbitkami, które wówczas utworzą ładną książkę. O życzeniu Pańskim otrzymania 100 egz[emplarzy] odbitek zapomniałem powiedzieć, lecz to już załatwię bez posiedzenia Komisji, jeżeli Pan tego koniecznie życzysz. Radzę jednak nie żądać tego i poprzestać na 50 egz[emplarzach], gdyż według regulaminu musiałbyś się zrzec należnego honorarium, które przecie wyniesie najmniej 150 zł[otych] za przypuszczalne 15 arkuszy druku.

Wiadomość o Kółku etnograficznym przyjęto w Komisji z należytym uznaniem i postanowiono uczynić zadość wystosowanym przez Pana żądaniom. Wszystkie tomy „Zbioru Wiadomości [do Antropologii Krajowej]” z wyjątkiem wyczerpanych już pierwszych 2-4 będą Wam wkrótce wyprawione, dalsze też tomy będziecie otrzymywać regularnie.

$\mathrm{Na}$ ostatek, na przedstawienie moje i nieobecnego na posiedzeniu O[skara] Kolberga, Komisja Antrop[ologiczna] w uznaniu wytrwałej osobistej pracowitości Pańskiej na polu etnografii ojczystej, a jeszcze bardziej w uznaniu chwalebnej inicjatywy

52 Prośba ta została wyrażona w liście z 30 XI 1889 (Kolberg 1969: 645). Z kolejnego listu (20 I 189o) dowiadujemy się, że Kolberg przekazał na rzecz kółka etnograficznego swoje wydrukowane prace (Kolberg 1969: 658). 
i gorliwości Pańskiej w zawiązywaniu i kierownictwie tak pożądanego stowarzyszenia, jakim jest Kółko etnograficzne - obrała wczoraj Pana jednomyślnie na swego człon$\mathrm{ka}^{*}$. O tym, po otrzymaniu podpisanego potwierdzenia przez Wydział III Akademii na najbliższym jego posiedzeniu, tj. 20 t[ego] m[iesiąca], zostanie Pan urzędownie zawiadomionym.

Czcigodny O[skar] Kolberg ze swojej strony przyjął odezwę waszą z najszczerszym zadowoleniem i oświadczył mi, że najdalej po nowym roku poleci księgarni Friedleina ${ }^{53}$ wyprawić pod adresem Pańskim dla Kółka etnograficznego wszystkie tomy swego Ludu i Mazowsza. Na odezwę też Pańską odpisze przy tym jak należy, skoro tylko będzie cokolwiek wolniejszym od naglących, a wiek jego znacznie przewyższających zajęć.

Później, gdy odsyłać będę Kochanemu Panu 2. część Jego rękopisu, pomówimy o nim cokolwiek. Teraz pilno mi przesłać Panu tę wiadomość, z dołączeniem najżyczliwszych i pełnych szacunku wyrazów.

Wasz

I. Kopernicki

* Występowałem z tym wnioskiem jeszcze przed 4-5 laty, lecz wówczas dla niektórych wcale błahych względów niektórzy uznali go za wczesny.

1890

12. (L)

Kraków, d[nia] 8 stycz[nia] 1890

\section{Szanowny i Drogi Panie!}

Zbieram się już od dawna odezwać się do Pana, lecz przez Święta tak jakoś nie domagałem, żem się zaledwo przed paru dniami zdobył na wyprawienie urzędowego zawiadomienia Go od Komisji Antropologicznej, o wybraniu Pana na Członka tej Komisji. Onegdaj zaś otrzymawszy od brata ${ }^{54}$ Pańskiego zapowiedziane pudełko z pisankami (niestety niewypróżnionymi lege artis), nie mogę już zwlekać, ażeby nie podziękować Panu Kochanemu za Jego łaskawość. Pisanki są szkaradne, to pewno, bo pochodzą ze wsi polskich, jak się domyślam, a lud polski, jak to wiadomo, rzadko gdzie, chyba w sąsiedztwie z Rusią, miewa pisanki, lecz kunsztu tego nie posiada i tworzy

53 Księgarnia Friedleina rozpoczęła działalność w roku 1810, jej założycielem był Jan Jerzy Fryderyk Friedlein (1771-1834). Jego syn Daniel Edward Friedlein (1831-1917) przejął księgarnię i założył w 1833 r. drukarnię, która działała do roku 1956. W roku 1878 Drukarnia Friedleina przejęła wyłączność na sprzedaż wydawnictw Akademii Umiejętności.

54 Prawdopodobnie chodzi tu o Mariana Udzielę. 
bazgraniny bardzo ubogie. Jeżeli nie te same, które otrzymałem, to inne podobne muszą zapewne istnieć i u Łemków. Zatracili oni niewątpliwie (tak samo jak akcent ruski) prawdziwie ruską twórczość w malowaniu pisanek. Potrzebuję wszakże przekonać się o tym faktycznie i dlatego proszę, abyś to Pan z łaski swojej miał w pamięci i przy Świętach Wielkanocnych postarał się o okazy ze wsi głębokiej Łemkowszczyzny, tj. z samych wierzchowin górskich bliżej od granicy węgierskiej. Na wiosnę przysłano mi kilkadziesiąt okazów znad górnego Sanu, od Bojków. Są to takie same niezdarne gwiazdeczki tylko, jak na tych, które teraz od Pana otrzymałem. Zdaje się więc, że w wyjątkiem Hucułów, którzy są mistrzami w ornamentyce, w ogólności sztuka pisania pisanek wielkanocnych została całkiem zatartą u górali ruskich. Mam nadzieję przekonać się o tym faktycznie tej wiosny.

Za łaskawe starania Pańskie o przysporzenie mi materiałów etnograficznych z Łemkowszczyzny wielce jestem obowiązany, Chociaż ani na plony obfite, ani na ich wielką przydatność nie bardzo liczę. $Z$ tych, które otrzymałem, doskonałe są nazwy rodowe (prawdopodobnie samych uczniów?) i pieśni z Ropicy Ruskiej, z Boguszy i po części z Kunkowy. Proszę bardzo napisać mi kiedyś przy sposobności, kto mianowicie dostarczył Panu tych pieśni i jakim sposobem od kogo je spisywał? Pieśni z Krywego (maksy$\mathrm{m}$ [alnie] Kobani) są do niczego, bo najwidoczniej powypisywane z książek po rusku drukowanych, i to przez kogoś nieumiejącego po rusku. Również z 2 całych zeszytów Mikołaja Gbura z Małastowa wypisałem zaledwo trzy i tych nie jestem pewny, czy je lud miejscowy śpiewa, reszta zaś są zbiorem [sic] najrozmaitszych piosenek niełemkowskich, bo nie ich mową pisanych, spisanych najwidoczniej z pamięci, a pochodzących z najrozmaitszych stron i źródeł drukowanych i niedrukowanych. Nie zrażajmy się tym jednak i zbieraj Pan z łaski swojej, co tylko się uda; zawsze z tego coś się do użytku wygrzebie - resztę, czego mi brakować będzie, wypadnie chyba samemu spisywać, upatrzywszy sobie jakich parę punktów na wycieczkę z dłuższym pobytem.

Druk Pańskiego Ludu ropczyckiego już się rozpoczął, lecz z przyczyny Świąt idzie bardzo powolnie. Nie gniewaj się Pan, że ani z mapki dodanej do rękopisu, ani z fotografii użytku nie zrobimy. Po rozmyśle i naradzie z Kolbergiem przekonaliśmy się, że nic one nie dodają do objaśnienia doskonałego opisu w tekście, więc obejść się bez nich można, a obchodzić się i oszczędzać się musimy, mając w tym roku budżet Komisji okrojony o całe 500 zł[otych], a rzeczy do drukowania moc. Drugą część rękopisu swego, zawierającą pieśni, musiałeś już Pan otrzymać. Na uporządkowanie ich, opatrzenie uwagami i przypiskami porównawczymi itp. mają dość czasu do końca października. Nie przestaję gniewać się na skąpstwo Szan[ownego] Zarządu Akademii, że zamiast V-XIII zbył Was tylko IX-XIII [tomami] „Zbioru Wiadomości do Antropologii Krajowej", ale na to rady nie mam.

Życzę z całego serca wszelkiego dobra i powodzenia Drogiemu Panu w tym nowym roku i polecając się Jego życzliwości, zapewniam o mym wysokim i szczerym szacunku 
Szan[ownemu] burmistrzowi gorlickiemu, $\mathrm{P}[\mathrm{anu}]$ Biechońskiemu ${ }^{55}$, proszę uprzejmie kłaniać się ode mnie. Kolberg dał przed Świętami polecenie księgarni Friedleina, aby przygotowała dla Kółka waszego cały komplet dzieł jego (z wyjątkiem Pokucia).

\section{3. (L)}

Kraków, d[nia] 27 lut[ego] 1890

\section{Szanowny i Drogi Panie!}

Dziś dopiero udało mi się uwinąć z tłumaczeniem na polskie [sic] i uporządkowaniem materiałów o Łemkach, którymi byłeś łaskaw mię obdarzyć, dziś więc dopiero składam dzięki najszczersze za ten cenny przyczynek, wszystko, a wszystko jest mi wielce przydatne, począwszy od cennych spostrzeżeń i uwag własnych Szanownego Pana, aż do zapisków poczciwego nauczyciela z Kwiatonia ${ }^{56}$, któremu przy pierwszej możności postaram się wywdzięczyć. Dziękuję za wszystko otrzymane i zapowiedziane, a upraszam o dalsze notatki podobne, przede wszystkim o własne Pańskie, ile ich ułowić zdołasz w swoich wędrówkach i gawędach z ludźmi świadomymi tych rzeczy, a także o kołataniu do takich nauczycieli jak ów z Kwiatonia, z Ropicy Ruskiej i Boguszy. Fotografia jest także doskonałą, szkoda tylko, że przedstawia samą młodzież, a zatem okazy niedojrzałe i mniej typowe niż osoby dorosłe. Czy nie można by Pana fotografa gorlickiego, który tak po mistrzowsku zdejmuje, namówić do pofotografowania górali pojedynczo w ich ubiorach powszednich i świątecznych, męskich i kobiecych? Chętnie bym nabywał od niego fotografie najbardziej typowe i zwyczajne $\mathrm{w}$ formie kart wizytowych, po cenie nawet dwakroć większej niż tutejsze Kriegera ${ }^{57}$, tj. po 40-50 c[entów] za sztukę. Może go Pan zapewnić, że na robieniu podobnych fotografii nigdy nie straci, bo są poszukiwane przez kunstkündlerów. A nasz Krieger za moją namową przed laty 20, oddawszy się temu specjalnie, stoi wcale świetnie, chociaż mieszkając na 3. piętrze, zwykłych fotografii nie robi wcale.

Bardzo obowiązany jestem Kochanemu Panu za objaśnienie mnie o Jabłonicy ${ }^{58}$ i Krasnem ${ }^{59}$, skąd pisanki wielkanocne pochodzą. Miałem je mylnie za wsie polskie. Sądzę jednak, że Rusini w tych wsiach nie są wcale Łemkami, jak inni prawdziwi górale, lecz należą do tej grupy podgórskiej Rusinów ${ }^{60}$, których poznałem w okolicach

55 Wojciech Biechoński (1839-1926), działacz społeczny i oświatowy, urzędnik, powstaniec styczniowy, burmistrz Gorlic.

56 Kwiatoń (łemk. Квятонь) - wieś na Łemkowszczyźnie w powiecie gorlickim, gmina Uście Gorlickie.

57 Ignacy (Izaak) Krieger (1817 lub 1820-1889), krakowski fotograf, pionier fotografii w Polsce, autor wielu zdjęć zabytków Krakowa.

58 Prawdopodobnie mowa o Jabłonicy, wsi na pograniczu Łemkowszczyzny i Bojkowszczyzny, w powiecie jasielskim, w gminie Skołyszyn.

59 Prawdopodobnie mowa o Krasnem, wsi w powiecie rzeszowskim, w gminie Krasne.

6o Mowa o Bojkach, ruskiej grupie etnograficznej zamieszkującej tereny na wschód od Łemków. 
Rymanowa $^{61}$, Sieniawy nad Wisłokiem ${ }^{62}$, Adrychowej i innych wsiach. Mieszkania ich, nie w kurnych chatach, są zupełnie inaczej zbudowane i noszą się oni bardzo odmiennie od Łemków z innych stron Rymanowa, szczególnie kobiety mają kurty sukienne osobliwszego kroju i włosy uczesują w ogromną grzywę, spadającą na czoło. Dokładne rozgraniczenie między takimi wsiami ruskimi na Podgórzu a prawdziwą Łemkowszczyzną będzie mi bardzo potrzebne. Jak zaś przyjść do tego bez umyślnej wycieczki w te strony, która mi jest niełatwą, doprawdy nie wiem. Chyba znowu udam się do pomocy Kochanego Pana z ułożonym w tym celu krótkim kwestionariuszem dla zebrania potrzebnych wiadomości za pośrednictwem znajomych Mu księży i takich nauczycielek, jak w Jabłonicy i Krasnem.

Druk Pańskiej pracy w „Zb[iorze] Wiad[omości] [do Antropologii Krajowej]” postępuje bardzo powolnie z powodu, że korektor właściwy, w ogólności bardzo nieżwawy, chorował do 2 tygodni. W tej chwili przyniesiono mi do rewizji 6. formę (o turoniu i początek szopki), niestety pomimo nalegania ustawicznego roboty przyśpieszyć nie jestem w stanie. Mam dotąd tylko pierwszą formę odbitą na czysto, gdy więcej uzbieram, wyszlę Kochanemu Panu pod opaską [?]. Jeżeli, jak się domyślam, zależy Panu na otrzymaniu honorarium, to po skończeniu druku tej 1. połowy postaram się, aby je Panu wysłano.

Zamierzone przez Kochanego Pana Notatki z podróży po Łemkowszczyźnie ${ }^{63}$ nie tylko nie mogą żadną miarą zawadzać mojej pracy o tym kraju, lecz, owszem, bardzo mi są pożądane, bo w nich znajdę niezawodnie nowe i doskonałe źródło, z którego niejedną rzecz zaczerpię. Bardzo więc szczerze namawiam Pana na tę pracę, którą rad będę powitać $\mathrm{w}$ „Wiśle”.

Prof[esor] Kałużniacki ${ }^{64} \mathrm{z}$ Czerniowiec o 2 lata przede mną podróżował po góralszczyźnie ruskiej, studiując przeważnie gwary ludowe. Jak mi mówiono wszędzie, musiał zebrać sporo materiałów mających także etnograficzne znaczenie. $Z$ upragnieniem największym czekam względem ogłoszenia jego pracy. Ks[iądz] Chylak ${ }^{65}$ jest mi dobrze znany z najdoskonalszego opisu obrzędów weselnych u Łemków (Liter[aturnyj] Skarbnik Ruskoj Matycy, r. 1871 ${ }^{66}$. Miałbym wielką ochotę i potrzebę wejść z nim w korespondencję, jeżeli jest człowiekiem uczynnym.

61 Rymanów (łemk. Риманів) - miasto na pograniczu Łemkowszczyzny i Bojkowszczyzny, powiat krośnieński, gmina Rymanów.

62 Sieniawa (łemk. Синява) - wieś na pograniczu Łemkowszczyzny i Bojkowszczyzny, powiat krośnieński, gmina Rymanów.

63 Praca ta jest częścią książki Udzieli Ziemia łemkowska przed pótwieczem...

64 Emil Kałużniacki (1845-1914), slawista, badacz języka staropolskiego, profesor i rektor (1889-189o) Uniwersytetu w Czerniowcach.

65 Wołodymyr Chylak (ukr. Володимир Хиляк) (1843-1893), pseud. Łemko Semko, Hieronim Anonim, W. Nielach, ukraiński i łemkowski pisarz i poeta.

66 Mowa o artykule W. Chylaka: В. Хиляк Свадебныи звичаи у Лемковъ, „Литературный сборникъ издаваемый Галицко-Русскою Матицею” 1871, s. 4-29. 
Ściskam Drogiego Pana najserdeczniej i wyrazy szczerego szacunku i przyjaźni zasyłam

I. Kopernicki

O materiałach z Kwiatonia potrzebuję kilkunastu objaśnień. Załączam [w] odpowiedzi zapytania, spisane pod n[umerem], na osobnej kartce. Proszę o uzyskanie odpowiedzi na nie, zapisanych tylko pod odpowiednim n[umerem] bez powtarzania samych pytań, które zachowałem ponumerowane u siebie.

14. (L)

Kraków, d[nia] 27 marca 1890

\section{Szanowny i Drogi Panie!}

Przed paru dniami otrzymałem od brata Pańskiego, P[ana] W[ielmożnego] Mariana, łaskawie mi przysłany przez Pana opis wesela łemkowskiego z Czarny ${ }^{67}$, nakreślony przez P[ana] Wład[ysława] Rusyniaka. Z wdzięcznością najszczerszą dla Kochanego Pana za ten nowy przyczynek do moich materiałów, włączyłem go już do właściwej kupki innych i w swoim czasie skorzystam niemało, bo zawiera wiele szczegółów odmiennych od obrzędów weselnych z innych stron Łemkowszczyzny mnie dostarczonych. Gdy wszakże niektóre z tych szczegółów nie są w opisie P[ana] Rusyniaka dość zrozumiale dla mnie opowiedziane, więc udaję się do Kochanego Pana z prośbą o uzyskanie od P[ana] Rusyniaka potrzebnych wyjaśnień na pytania, które w dodatku do tego listu niżej wypiszę.

Od 2 tygodni wziąłem do rąk własnych wyłącznie korektę druku Pańskiej pracy o Ropczyckiem i odtąd poszło już sporzej. 5 arkuszy jest już gotowych, reszta składa się. Za tydzień przyszlę Panu na Święta to, co będzie gotowego do przejrzenia, a po Świętach zaraz zechce mi to Pan zwrócić, bo mi te odbitki będą koniecznie potrzebne przy dalszej korekcie, chociażby dla zapobieżenia takim omyłkom w numerowaniu rozdziałów, jakie z wielką przykrością dla mnie wkradły się uprzednio przez nieuważnego korektora, na którego byłem się spuścił.

Brat Pański uczynił mi nadzieję, że może podczas Świąt wybierzesz się Pan na jaki dzień do Krakowa. Spodziewam się i ja skorzystać z tego, licząc na łaskawe odwiedziny Kochanego Pana. Tymczasem zaś na zbliżające się Święta zasyłam moje życzenia najszczersze i powtarzam wyrazy mego wysokiego szacunku.

Zawsze najżyczliwiej oddany i obowiązany wielce

I. Kopernicki

67 Czarna (łemk. Чорна) - wieś na Łemkowszczyźnie w powiecie gorlickim, gmina Uście Gorlickie. 


\section{5. (K)}

Szanowny i Drogi Panie!

Kraków, 10 w[rześnia] 1890

Periculum in mora. Mam w korekcie 18. formę Ropczyc o przesądach itp., gdzie przy każdym szczególe podane są litery: R, Ch, Cz, P, Ł, R, Gnojn., oznaczające miejscowości, lecz gdy w przedmowie nie jest to oznaczone, co te skrócenia znaczą, więc należy to tutaj objaśnić w przypisku albo (co uważam za właściwsze, ponieważ z małymi wyjątkami wszędzie stoi tylko R) całkiem opuścić. Proszę więc o odpowiedź natychmiastową, bo tak zagadkowo tego zostawić niepodobna. Po przesądach będzie jeszcze rozdział Gry i na tym zakończyć muszę tę część pierwszą, gdyż ta już 8 arkuszy druku zajęła. Bajki odłożymy do drugiej części, na rok przyszły, gdzie razem z pieśniami i zagadkami utworzą dział jednorodny samych utworów ludowych. Tak będzie dobrze. Proszę o odpowiedź i zwrot arkuszy odbitych na czysto i ściskam Kochanego Pana po przyjacielsku.

Wasz

I. Kopernicki

1891

16. (K)

Kraków, 7 stycznia 1891

Szanowny i Kochany Panie!

Przykro mi to, że na samym początku nowego roku, w którym życzę Panu wszelkiego dobra i pomyślności, odzywam się z wiadomością niemiłą. Druk Pańskiego Ludu ropczyckiego nie może być skończony w t. XV i gadki, jako cz[ęść] 3. Pańskiej pracy, została odłożoną do t. XVI, który drukować się będzie dopiero w jesieni. Do tego rozćwiartowania zmusiła mię konieczność ta: otrzymawszy rękopis Pańskich pieśni, oddałem je natychmiast do drukarni i nie miałem czasu rozpatrzeć się i obliczyć, że jest ich za dużo, boś Pan dodał bodajże drugie tyle do pierwotnego rękopisu, posłanego Panu do uporządkowania tylko - opatrzyłem się dopiero wtedy, gdy druk ich został skończony i zajął 8 arkuszy! nie licząc melodii 150, których druk wynosi 45 zł[otych]. Gdyby więc drukować dalej i gadki, to praca Pańska zajęłaby 12 arkuszy, tj. przeszło 2 razy więcej niż się przeznacza dla jednej w tym samym tomie, a skutkiem tego ekscesu nie starczyłoby w tym tomie miejsca dla innej pracy, przygotowanej do tegoż tomu i bardzo ważnej. Za ten więc nadmiar pieśni (bez którego można było obejść się doskonale) musisz Pan czekać na swoje odbitki aż do jesieni. Honorarium zaś za pieśni otrzymasz Pan teraz.

Pozdrawiam po przyjacielu zawsze pełen szacunku

I. Kopernicki 


\section{7. (L)}

Kraków, d[nia] 14 marca 1891

Szanowny i Kochany Panie!

Mając zaraz po Świętach 2 tygodnie czasu, zamierzam go użyć na wycieczkę do Łemków w tym celu, aby zatrzymawszy się przez ten czas w jednej okolicy, przypatrzyć się im nieco dokładniej, nasłuchać się ich mowy, uzbierać osobiście jakiś zapas wiadomości o ich zwyczajach, obrzędach, wierzeniach itp., spisać ciekawsze bajki i pieśni, a także za pomocą mego podróżnego aparatu fotograficznego nazdejmować sobie spory zapas typowych fotografii Łemków, ich mieszkań itp.

Jako punkt główny projektowanej tej wycieczki obrałem sobie Grab i okolice na wierzchowinach Wisłoki. Pisałem o tym do zacnego proboszcza tamtejszego ks. Mereny, zapytując go, czy to jest pora przyjazna dla mnie i czy mu nie będę gościem uciążliwym? W oczekiwaniu odpowiedzi jego i nie mając pewności, czy dobry wybór zrobiłem, udaję się po łaskawą radę i w danym razie o pomoc i protekcję od Szanownego Pana. Czy sądzisz Pan, że ta pora, początek wiosny, jest dobrze obraną dla mego zadania? Jeżeli tak, to czy nie byłbyś łaskaw upatrzyć dla mnie i zamówić taką stację obserwacyjną, np. w Małastowie, Gładyszowie lub Smerekowem ${ }^{68}$, po drodze do Grabu - gdzie mógłbym znaleźć, chociażby za opłatą, jaki pokoik osobny na mieszkanie z pościelą i strawą jakąkolwiek. Głównie zaś, czy znajdę tam takiego opiekuna, który mi sprowadzi potrzebnych bajarzy, śpiewaczki itp. osoby potrzebne?

Jeżeli spełnieniu mego zamiaru nie przeszkodzi coś niespodziewanego, to, ma się rozumieć, będzie mi bardzo miło najprzód odwiedzić Kochanego Pana w Gorlicach i stamtąd według wskazówek jego udać się dalej. Przedtem wszakże potrzebuję dowiedzieć się, czy zastanę Pana w domu i czy projekt mej wycieczki aprobujesz?

Oczekuję więc słówka odpowiedzi od Kochanego Pana i dosyłając Mu najszczersze życzenia na zbliżające się Święta, zostaję zawsze z szacunkiem prawdziwym i przyjacielską życzliwością.

Szczerze oddany Wasz

I. Kopernicki

\section{Izydor Kopernicki's 1887-1891 letters to Seweryn Udziela Summary}

The paper is an edition of 11 letters and 6 postcards sent by Izydor Kopernicki to Seweryn Udziela in years 1887-1891, stored in S. Udziela Etnographic Museum in Cracow.

68 Smerekowiec (łemk. Смерековець) - wieś na Łemkowszczyźnie w powiecie gorlickim, gmina Uście Gorlickie. 